\title{
HISTORY OF THE ENTRY OF ISLAM IN THE MUSLIM MINORITY AREA OF TANA TORAJA
}

\author{
Qaharuddin Tahir ${ }^{1}$ \\ Sattu Alang ${ }^{2}$ \\ Nurhidayat Muhammad Said ${ }^{3}$ \\ Abd. Halik ${ }^{4}$ \\ Program Pascasarjana UIN Alauddin Makassar ${ }^{1}$ \\ Universitas Islam Negeri Alauddin Makassar ${ }^{2,3,4}$ \\ qaharuddin.tahir@gmail.com
}

\begin{abstract}
Tana Toraja is known as the only district in South Sulawesi with a Muslim minority population. This research discusses the early history and route of entry of Islam in Tana Toraja. This research is a qualitative research, with a phenomenological approach in the context of da'wah, communication and history. Data collection was carried out by observation, interviews and literature review. Data analysis techniques were carried out, referring to the data analysis principles proposed by Miles and Huberman. Which offers an interactive model analysis system, which consists of three components, namely data reduction, data display, and drawing and verifying conclusions. The results showed that the entry of Islam in Tana Toraja began with the interaction of local people with traders from Bugis Luwu, Bone and Sidenreng, then followed by the Islamization of two Toraja nobles, namely Puang Sondong in Batualu and Rangga in Madandan.
\end{abstract}

Keyword: Islam; History; Minority

\section{PRELIMINARY}

Islamization occurred in South Sulawesi in the 17th century beginning with the conversion of the king of Gowa-Tallo I 'Mallingkang Daeng Mannyonri Karaeng Tumenanga ri Bontobiraeng, who later changed its name to Sultan Alauddin Awwalul Islam. After that there was the Islamization of kingdoms in South Sulawesi, including: the kingdoms of Sidenreng Rappang and Soppeng (converted to Islam in 1609 AD), following Wajo in $1610 \mathrm{AD}$, and finally Bone in $1611 \mathrm{AD}^{1}$. The interesting thing about this incident is that there is no significant influence on the development of Islam in Tana Toraja. The Islamization carried out by the Kingdom of Gowa does not touch Tana Toraja. Meanwhile, almost all areas in South Sulawesi have been influenced by Islamic teachings.

Islamization in Tana Toraja was more influenced by the Luwu Kingdom, through trade and marriage relations, the Sidenreng Kingdom through trade relations and the Tallu Batu Papan Kingdom in the Enrekang area through trade and kinship relations.

Based on historical records, Islam actually entered Tana Toraja earlier than the entry of Christianity. Islam has entered Tana Toraja since the late 17th century or early 18 th century. This can be proven by the existence of an old tomb in Sanggala, about 10

\footnotetext{
${ }^{1}$ Ahmad M. Sewang, Islamisasi Kerajaan Gowa Abad XVI sampai Abad XVII, (Jakarta: Yayasan Obor Indonesia, 2005), p. 111-119
} 
$\mathrm{km}$ from Makale. Above the tomb's headstone, there is an inscription using Arabic letters. Although it does not clearly state the year of its creation, the tomb is thought to belong to a Bugis merchant or Bugis trader who died in Tana Toraja about 300 years ago. ${ }^{2}$ Meanwhile, Christianity only entered Tana Toraja in $1906 .{ }^{3}$ However, the development of Islam is far behind the development of Christianity which is much faster, both in terms of the number of followers and the formation of the people.

Tana Toraja is the only district in South Sulawesi that belongs to an area with a minority Muslim population. There is even a stigma in society that Toraja people are Christian, but based on statistical data this is not the case, not all of the population is Christian, there are $12.26 \%$ of the population are Muslims out of 279,541 people.

This research intends to trace the history of the entry of Islam in Tana Toraja, with the aim of identifying the early history of the entry of Islam in Tana Toraja.

\section{THEORETICAL STUDIES}

Herodatus, who is nicknamed The Father of History, holds that history does not develop forward and with a definite purpose, but moves like a circular line whose heights are caused by the human condition, namely hybris (grafts) and memesis (imitation). ${ }^{4}$ As the cycle continues, historical events sometimes bear similarities to other events.

Ibn Khaldun in his Muqaddimah defines history as a record of human society or world civilization, about changes that have occurred in society or about all kinds of changes that have occurred in society at that time. ${ }^{5}$ Changes that occur in society can be in the form of progress and successes that have been achieved, or it can be in the form of failures that occur in society.

Meanwhile, Aristotle defines historia to give the title of one of his books in the sense of a collection of materials about something according to certain themes. ${ }^{6}$ In this sense history has a broader scope, as a concept of science. Not just talking about stories or events.

\section{RESEARCH METHODOLOGY}

This research is a field research, using qualitative research as a problem-solving procedure in research, by describing / describing the condition of the research subject / object (person, institution, community, etc.) based on visible facts or as they are. ${ }^{7}$ The main characteristic of field research is the direct involvement of the researcher on the object under study.

This social phenomenon will be studied in the historical research of the contact between Islam and the indigenous people of Tana Toraja. Qualitative descriptive research is a research procedure that produces descriptive data in the form of expressions

\footnotetext{
${ }^{2}$ Hendri Firzani, Geliat Syiar Islam di Tana Toraja, arsip.gatra.com (5 Maret 2019).

${ }^{3}$ Abednego T. Paonganan, Dugaan Orang Toraja Dominan Beragama Kristen. archive.org (5 Maret 2019).

${ }^{4}$ Sulasman, Metodologi Penelitian Sejarah "Teori Metode Contoh dan Aplikasi, p. 17

${ }^{5}$ Sulasman, Metodologi Penelitian Sejarah "Teori Metode Contoh dan Aplikasi, p. 17

${ }^{6}$ Daliman, Metode Penelitian Sejarah, Yogyakarta, Ombak. 2018

${ }^{7}$ Nawawi Hadaru, Metode Penelitian Bidang Sosial, (Yogyakarta: Gajah Mada University Press, 1993), p. 63
} 
from one's own people or observed behavior. ${ }^{8}$ the procedure carried out in this research is to reveal the facts in the field by obtaining data directly from people who are directly involved or people who know what is related to the research being carried out.

Lincoln and Guba explain that qualitative research opens up greater opportunities for a direct relationship between researchers and respondents or research objectives. So it is easier to understand the phenomenon described than if the term is only based on the views of the researchers themselves. ${ }^{9}$

This research was conducted in Tana Toraja Regency, the only district in South Sulawesi with a minority population. The area of Tana Toraja Regency is recorded at $2,054.30 \mathrm{~km}^{2}$, covering 19 districts.

The local Torajan religion is called Aluk Todolo (Aluk means "Religion", To means "people" and Dolo means, "ancestors"). Also commonly abbreviated as Alukta (Religion where the suffix ta means "We"). This religion derives from two main teachings, first, which is called Aluk 7777 or Aluk Sanda Pitunna ("The All-Seven Aluk"), and second, Aluk Sanda Saratu '("The One Hundred Aluk"). Both the Aluk Sanda Pitunna which was spread by Tangdilino 'and the Aluk Sanda Saratu' which was spread by Puang Tamborolangi ', which the public believed was a person who came down from the sky. ${ }^{10}$

The approach used in this research is a qualitative approach based on phenomenological and humanistic philosophies. In the context of communication, da'wah and history, as well as in the broader context of social sciences and behavioral science. ${ }^{11}$

Theories in the phenomenological tradition assume that people actively interpret their experiences and try to make sense of the world with their personal experiences. ${ }^{12}$ Phenomenologists emphasize the real experience of a researcher, therefore real experience in the field becomes the main data of a reality.

Data sources consist of primary data and secondary data, primary data is obtained through field research by conducting observations and interviews with selected sources, key informants will be selected consisting of Islamic religious figures and da'wah practitioners, both personal, and from government agencies or Islamic mass organizations. who understands about the history of the entry of Isla $\mathrm{m}$ in Tana Toraja.

Data collection techniques are the most important step in research, because the main purpose of research is to get data. Without knowing the data collection technique, the researcher will not get data that meets the established data standards. ${ }^{13}$

The research instrument is a tool for extracting primary data from respondents as the most important data source in a research servei. Social science research instruments are generally in the form of questionnaires and interview guides. All types

\footnotetext{
${ }^{8}$ Robert Bogdan and Steven J. Tailor, Dasar-Dasar Penelitian Kualitatif. Terj. A. Khosin Afandi (Surabaya: Usaha Nasional, 1993), p. 30

${ }^{9}$ Y.vonna S. Lincoln and Egon Guba, Naturalistic Inquiy (Beverly Hills: SAGE Publication, Inc., 1990), p. 19

${ }^{10}$ Stanislaus Sandarupa, Glokalisasi Spasio-Temporal Agama Aluk To Dolo oleh Agama Kristen di Toraja, http://jurnal.unpad.ac.id/sosiohumaniora/article/view/5677/3008, (March 1, 2015)

${ }^{11}$ Pawito, Penelitian Komunikasi Kualitatif, (Yogyakarta: LKIS, 2008), p. 36

${ }^{12}$ Stephen W. Litllejohn and Karen A. Fos, Teori Komuniaksi "Theories Oh Human Communication", (Jakarta: Salemba Humanika, 2009). p. 57

${ }^{13}$ Sugiyono, Metode Penelitian Kombinasi: Mixed Methods, (Bandung: Alfabeta, 2013), p. 308
} 
of research instruments contain a series of questions about a matter or problem that is the main theme of the research. ${ }^{14}$

In qualitative research, the research instrument or tool is the researcher himself. Therefore, researchers as an instrument must also be "validated" to what extent qualitative researchers are ready to carry out research which then goes to the field. Validation of researchers as an instrument includes validation of understanding qualitative research methods, mastery of insight into the field under study, readiness of researchers to enter research objects, both academically and logistically. The one who validates is the researcher himself through self-evaluation. ${ }^{15}$

In this study, data analysis was carried out, referring to the principles of data analysis proposed by Miles and Huberman. Which offers an interactive model analysis system, this analysis basically consists of three components, namely data reduction, data display, and drawing and verifying conclusions. ${ }^{16}$

\section{RESULTS AND DISCUSSION}

The presence of Islam in Tana Toraja, has a long history, involving many figures with various historical events as their background. Based on historical records, the initial contact between Islam and the indigenous people of Toraja began in the 17th century.The history of the entry of Islam in Tana Toraja can be traced through three main routes, including:

\section{A. Regional Relations and Marriage Pathways}

The Tana Toraja region from before the Dutch colonialism until 1961, was included in the territory of the Luwu Kingdom. So that the history of civilization, culture and religion of the Tanah Toraja region, directly or indirectly, is influenced by the dynamics that occurred in the Luwu Kingdom. Mentioned in the Luwu Book of Revolution, the Luwu kingdom has three broad areas, each of which is led by a Regional Head who holds the title: Madika Bua, Madika Pon rang and Makole Baebunta. The Madika Bua area stretches from the village of Bua to the West, through the Pantilang mountains, on to Tana Toraja to the limit of Enrekang. ${ }^{17}$ Currently these areas are included in three different districts, namely Luwu Regency, Tana Toraja Regency and Enrekang Regency.

Bigalke quoted Van Lift as suggesting that Luwu's claim to To Riaja (Tana Toraja) was based on the tribute-paying relationship it formed with many of Tana Toraja's rulers. ${ }^{18}$ This is evidence of the relationship between the Luwu Kingdom and Tana Toraja.

The arrival of Islam for the first time in Luwu was estimated at the end of the century 16 or early 17 th century. Datok Suleman from Minangkabau was the first to introduce Islam. in 1607-1641. The king who ruled at the time of the arrival of Islam in Luwu was Patiarase, the Islamic King of Patiarase, the beginning of the Luwu Kingdom

\footnotetext{
${ }^{14}$ Bagong Suyanto and Sutinah (editor), Metode Penelitian Sosial: Berbagai Alternatif Pendekatan, (Jakarta: Kencana, 2005). p. 59

${ }^{15}$ Sugiyono, Metode Penelitian Kombinasi: Mixed Methods, p. 305

${ }^{16}$ Pawito. Penelitian Komunikasi Kualitatif, (Cet II; Yogyakarta: LKIS, 2008), p. 104

${ }^{17}$ Sanusi Dg, Mattata, Luwu dalam Revolusi, (Makassar: Bhakti Baru, 1967), p. 3

${ }^{18}$ Terance W, Bigalke, Sejarah Sosial Tana Toraja,, (Yogyakarta: Ombak, 2019), p. 86
} 
having a king who embraced Islam. ${ }^{19}$ Since then Islam has become the official religion of the Kingdom.

The influence of Luwu in Tana Toraja, before the 19th century was very strong, especially in the northern part of Tana Toraja. As Bigalke points out, the northern region was historically within the colony of the Luwu Kingdom, an ancient Bugis state situated along the west coast of the bay known by the same name. In the 19th century any ties that previously tied the Sa'dan highlands (Tana Toraja) to Luwu had disappeared, and the Village Heads in the south oriented themselves to the federation of the foothills of Duri Enrekang (Massenrempulu) and the Bugis states to the south. ${ }^{20}$ This federation has influenced the relationship between Luwu and the areas in the south directly adjacent to Enrekang.

Toraja language is one of the languages that is used as a liaison language in kingdoms and everyday people's lives. This is as stated by Sanusi Dg. Mattata that:

"The languages used as the language of liaison in royal life and in the daily life of the people are Toraja and Bugis. ${ }^{2} 1$

Language is a reflection of culture, so that the choice of language in communicating reflects the culture of that community. As stated by Larry A. Samavor that:

"Language is also a another feature common to a culture. So important is language to every culture that Haviland and colleagues say, "Without our capacity for complex language, human culture as we know it would not exist". Language not only allows its members to share thoughts, feelings and information, but is also the main method of spreading culture. ${ }^{\prime 2} 2$

Language is not only a reflection of culture, but also as a control and mechanism for closeness of relationship. This is as stated by Charles R. Berger that:

"Through language, the identity of the goal of status and power is manifested. Language is able to function as a control as well as a mechanism for closeness of relationship. Bahasapun is able to cause and reflect conflict between groups. ${ }^{23}$

Other relationships such as political relations, trade, kinship relations and also marital relations.

The spread of Islam in Tanah Toraja, which has begun to spread, is difficult to prevent, because the development of dakwah continues, as long as Muslims have access to the area, this is as stated by Sanusi Dg. Mattata.

The desire to separate from Luwu did not come true, as long as the existence of the Luwu Kingdom, Tana Toraja remained in the territory of the Luwu Kedatuan. Tana Toraja just officially separated from Luwu after the issuance of Law no. 29 of 1959

\footnotetext{
${ }^{19}$ Sanusi Dg. Mattata, Luwu dalam Revolusi, (Makassar: Bhakti Baru, 1967), p. 70

${ }^{20}$ Terance W. Bigalke, Sejarah Sosial Tana Toraja, p. 17

${ }^{21}$ Sanusi Dg. Mattata, Luwu dalam Revolusi, (Makassar: Bhakti Baru, 1967), p. 13

${ }^{22}$ Larry A. Samavor, dkk, Komunikasi Lintas Budaya, p. 31

${ }^{23}$ Charles R. Berger et al, Handbook IImu Komunikasi, p. 122
} 
which dissolved the status of Swapraja and Neo-Swapraja throughout South Sulawesi by forming 13 Level II regions. ${ }^{24}$

The relationship between Luwu and Tana Toraja over time, including in the spread of Islam, occurs peacefully and not through coercion and violence or war. In the historical record of the role of Luwu in spreading Islam in Tana Toraja, there are at least two facts that indicate this relationship, namely through:

\section{Marriage of Puang Sondong with Descendants of Luwu}

Puang Sondong is a Tana Toraja aristocrat who has broad influence and is an important figure in the history of the entry of Islam to Tana Toraja. The people of Tana Toraja at that time generally had Aluk Todolo's belief as a religion, as did Puang Sondong before embracing Islam.

Based on the lineage of descent, Puang Sondong is the 23rd descendant of Puang Tamboro Langi ', the first ruler to rule widely in Tana Toraja. Having thick blue blood, Puang Sondong has an important position in society. Puang Sondong seven siblings, the seven of whom are known as Puang Pitu which means seven kings or nobles.

Puang Pitu is known as one of the rulers in Tallulembangna, there are seven children of Puang Pararrak descent from Kaero / Batu with Puang Tumba 'Manu' from Tongkonan Otin Mengkendek, the seven brothers according to Dahlan Bangapadang, among others ${ }^{25}$ :
a) Puang Pasanggang
b) Puang Sanggalangi '
c) Puang Tandi Payuk
d) Puang Bandakka
e) Puang Sondong
f) Puang Bangngalangi '
g) Puang Tappe '

Puang Pasanggang was appointed as Palodang X Officer at Sangalla ', Puang Sanggalangi' was appointed as Puang Paetong Officer at Mengkendek. Even though Puang Sondong did not serve as Palodang, he was still a respected figure in his community. After a group or deliberation at Salassa (Tongkonan Layuk) Sangalla 'it was decided that Puang Sondong (Puang Rondo-Rondo would follow the religion of his future wife, namely Islam. As told by Dahlan Kembong Bangapadang in the book Toraja Tongkonan and Harmony by Nurdin Baturante. ${ }^{26}$

The relationship between the seven siblings is very harmonious, there has never been friction, let alone war between them. Likewise, after Puang Sondong had embraced Islam, even according to Dahlan Bangapadang, at the residence of their parents in Kaero, the plates used by Puang Sondong were separated, so as not to mix with foods that are

\footnotetext{
${ }^{24}$ Sanusi Dg. Mattata, Luwu dalam Revolusi, p. 7

${ }^{25}$ Dahlan Bangapadang (49 years), Tana Toraja traditional leader, interview, Marinding, Kab. Tana Toraja, July 7, 2020.

${ }^{26}$ Dahlan Bangapadang's statement in the book, Toraja Tongkonan and Harmony, p. 552
} 
prohibited in Islam. ${ }^{27}$ The seeds of tolerance are starting to grow from this family. Respect for Puang Sondong's choice to embrace Islam is still appreciated.

The entry of Islam to Tana Toraja began with the marriage of Puang Sondong with two brothers Sabarra'na and Sabanni'na, descendants of the Luwu aristocracy who lived in Suso Te'tekan. ${ }^{28}{ }^{29}$ This event occurred around 1750.

At the beginning of his marriage he settled in Suli, when he was old he returned to Batualu. Puang Sondong has seven brothers and only he is Muslim. ${ }^{30}$

The communication process that occurs in a person's religious conversion experiences different circumstances, where a person's social identity changes along with the transfer of belief. The initial identity as a follower of Aluk Todolo turned into an Islamic identity. Tajfel and Turner put forward the social identity theory, which argues that a person's social identity is determined by the group to which he belongs. Researchers and social identity theorists argue that "people are motivated to join the groups that are most attractive and / or provide benefits to the groups they belong to. ${ }^{31}$

As a respected figure, Puang Sondong is still accepted as a member of the group to build solidarity together in building his community. In face negotiation theory, there is what is called facework solidarity, which is dealing with someone accepting another person as a member of an in-group. Solidarity improves the relationship between two people who are talking. This means that differences are minimized and togetherness is emphasized through informal language and shared experiences. ${ }^{32}$

Communication is a tool to form identity and also change mechanisms. Your identity, both in the eyes of yourself and others, is shaped when you socially interact with other people in your life. ${ }^{33}$ This marriage that eventually produced offspring, is evidence that shows that this marriage, is fine, and succeeded in uniting different cultural and religious backgrounds.

Symbolic interactionism rejects the idea that individuals are passive organisms whose behavior is determined by forces or structures that exist outside of themselves. Because individuals continue to change, society changes through interaction. ${ }^{34}$ Puang Sondong's interaction with the community causes the structure of the community to change. In terms of religious beliefs, some of them embraced Islam. While others still believe in Aluk Todolo. This change in belief will shape and change the structure of society.

Puang Sondong has five children who all embrace Islam following their parents, they are scattered in various places in Tana Toraja and Enrekang / Duri. Descendants of Kalling or Puang Pata spread widely to the southern tip of Toraja, which borders Enrekang Regency, namely Lembang Uluway. The existence of Puang Sondong descendants who have embraced Islam, made Uluway become one of the important areas

\footnotetext{
${ }^{27}$ Dahlan Bangapadang (49 years), Tana Toraja Regency Customary Leaders, Interview, Marinding, Kab. Tana Toraja, July 7, 2020.

${ }^{28}$ Syamsuddin Faisal (65 years), Former Head of KUA Mengkendek District, Interview, Mengkendek, Tana Toraja, October 16, 2019.

${ }^{29}$ Muhammad Ali Laso 'Pasa' (90 years old), Former Member of the Tana Toraja Regency DPRD 1977-1982 Period and Former Head of Lembang Uluway, Interview, Kampung Rony, 19 October 2019.

${ }^{30}$ Muhammad Ali Laso 'Pasa' (90 years old), Former Member of the Tana Toraja Regency DPRD 1977-1982 Period and Former Head of Lembang Uluway, Interview, Kampung Rony, 19 October 2019.

${ }^{31}$ Ricard West and Lynn H. Turner, Teori Komunikkasi Analisis dan Aplikasi, p. 218

${ }^{32}$ Ricard West and Lynn H. Turner, Teori Komunikkasi Analisis dan Aplikasi, p. 163

${ }^{33}$ Stephen W. Littlejohn and Karen A. Foss, Communication Theory, p. 131

${ }^{34}$ Deddy Mulyana, Qualitative Research Methods, h. 61
} 
in the spread of Islam in Tana Toraja, and succeeded in building a mosque in Kampung Rony as the first mosque in Tana Toraja. ${ }^{35}$

The Islamic Puang Sondong inspired many of the aristocratic descent, who had the same lineage as Puang Sondong who were attracted to and embraced Islam. Among the descendants of this clan who embraced Islam include Puang Sangalla 'and three siblings from one mother, among others:

a) Puang To'lamba

b) Puang Palion

c) Puang Indo 'Limbong

Puang Sangalla 'five siblings from one mother, only one person who does not embrace Islam and still believes in Aluk Todolo. Meanwhile, of the four descendants of Puang Sangalla 'three of them embraced Islam, among others:
a) Puang Paliwan
b) Puang Lai 'Rinding
c) Puang Palayukan Tinggi. ${ }^{36}$

One descendant of Puang Sangalla 'who did not embrace Islam, namely Puang

Marriage relationships lead to negotiations not only about what the couple wants for themselves and for the relationship itself although this is always a part of it, but about support and / or threats to cultural identity itself. There is a great deal of potential for visual threats related to culture because cultural identity is often large in that relationship. ${ }^{37}$

Part of the communication difficulty stems from the fact that cultural groups or subcultures within a culture have different sets of norms. ${ }^{38}$

Family families in Tana Toraja are united in a strong kinship bond with the existence of the Tongkonan or Banua Tongkonan, namely the Toraja traditional house which generally functions as follows, Tongkonan a symbol of power, as a symbol and center of family history, a place of fostering unity, as family pride, a place of implementation traditional ceremonies and places of deliberation. ${ }^{39}$

The large family tongkonan of Puang Sondong are located in Kaero / Batu and Tongkonan Otin Mengkendek. From his father's side, Puang Pararrak in Kaero / Batu, while from his mother's side, Puang Tumba 'Manu', at Otin Mengkendek. ${ }^{40}$ said that:

Syamsuddin Faisal, the former head of KUA of Mengkendek sub-district who

\footnotetext{
${ }^{35}$ Syamsuddin Faisal (65 Years), Former Head of the Office of Religious Affairs (KUA), Kec. Shortening, Interview, Ge'tengan Kab. Tana Toraja, 18 October 2019

${ }^{36}$ Dahlan Bangapadang (49 years old), Tana Toraja traditional leader, interview, Marinding, July $5,2020$.

${ }^{37}$ Stephen W. Littlejohn and Karen A. Foss, Teori Komunikasi, p. 297

${ }^{38}$ Deddy Mulyana, Ilmu Komunikasi Suatu Pengantar, p. 7

${ }^{39}$ Nurdin Baturante, Toraja Toraja Tongkonan dan Kerukunan, p. 233-235

${ }^{40}$ Dahlan Bangapadang (49 years old), Tana Toraja traditional leader, interview, Marinding, July 5,2020
} 
"The first mosque in Tana Toraja was built in Rony, still in the form of a Mushallah or Langgar, as a place for praying for five times a day, this building is still very simple, with thatched roofs and fibers." ${ }^{11}$

"The mosque in Rony is one of the first three mosques in the land of Duri, these three mosques have become the center of the spread of Islam, the existence of this mosque has received recognition from Enrekang, according to the oral story of the community the three mosques only have one mushap al-Quran." 42

The standard concept of Mead is identical to what Schutz calls himself in a reflective attitude that looks back at work actions done in the past (modo praeterito). Schutz considers this self who performs past actions as a partial self and as a role taker. ${ }^{43} \mathrm{~A}$ solid self-concept of an individual when joining a group will give color and influence to the group. And this is evident in the Islamic Puang Sondong, which has an influence on his community groups and also on his descendants.

The presence of Puang Sondong as a leader in his community who has different beliefs, namely Aluk Tododolo, from a communication perspective he can be a good communicator to convey his preaching, because he is a trusted and respected figure in society. However, due to his limited knowledge of religion and heavy da'wah challenges, until now the footprint of Islam in Batualu is not very prominent. However, it should be noted that the descendants of Puang Sondong played a major role in the spread of Islam in the southern area of Tana Toraja, which borders the Enrekang district. ${ }^{44}$

Puang Sondong as a communicator who directly or indirectly has an influence on his community, this can be seen by the development of Islam through his offspring. One of the things that can guarantee success in communication relationships is the credibility of sources, sources that are believed to influence the communicant.

\section{Rangga's marriage with Opu from Luwu}

Rangga is a native Toraja woman who was born and lives in Madandan. It is estimated that he converted to Islam in 1876-1880. ${ }^{45}$ Initially, the presence of Islam in Madandan was due to the marriage between Rangga and an Opu from Luwu named Opu daeng Makaluk. Because of this marriage, Rangga converted to Islam.

Rangga is an influential nobleman in the Madandan area. Even though she is a woman, she is a person who is respected and respected. With Rangga's Islam, he invited his family and relatives to embrace Islam, pada lot of people initially followed it, but

\footnotetext{
${ }^{41}$ Syamsuddin Faisal (65 Years), Former Head of KUA Mengkendek District, Ge'tengan Interview, October 18, 2019.

${ }^{42}$ Muhammad Ali Laso 'Pasa' (90 years), Former Member of the Tana Toraja Regency DPRD 1977-1982 Period and Former Head of Lembang Uluway, Interview, Kampung Rony, Kab. Tana Toraja, 19 October 2019.

${ }^{43}$ Deddy Mulyana, Metodologi Penelitian Kualitatif: Paradigma Baru Ilmu Komunikasi dan Ilmu Sosial Lainnya, p. 88-89

${ }^{44}$ Muhammad Ali Laso 'Pasa (90 Years), Former Member of the Tana Toraja Regency DPRD 1977-1982 Period, and Former Head of Lembang Uluway, Interview, Rony, Kab. Tana Toraja, 19 October 2019.

${ }^{45}$ Nurdin Baturante, Toraja Tongkonan dan Kerukunan, (Makassar: Pustaka Al-Zikra, 2014), p. 118.
} 
over time, because of their lack of guidance and limited knowledge of the teachings of Islam, some of them returned to their original religion. ${ }^{46}$

Rangga has five siblings, and only he embraces Islam. But Rangga's conversion to Islam was inseparable from the role of his brother, who married him off to the nobility of Luwu. At first, Daeng Makkaluk, who was Muslim, was asked for help by his brother, Rangga, named Ampulembang, to help him fight against Pong Tamba in order to fight for influence and power, because at that time it was an era of war between tribes or community groups to fight for power in society.

KejadThe war between Pong Tamba and Ampulembang, assisted by Lullu ', a brave man from Rembon, occurred around the 1800s, long before Indonesia's independence, namely in 1945. As it is known, before independence there was no unifying power. So each group or tribe has its own ruler. Likewise what happened in Madandan and other places at that time.

The struggle for power over the assistance of Arung from Luwu named Opu Daeng Makkaluk akhirnya won by Ampulembang. In return for his services, Opu Daeng Makkaluk married his younger sister who was famous for her beauty, named Rangga. This marriage became the forerunner of the presence of Islam in Madandan. ${ }^{47}$

Rangga is the descendant of an influential person in Madandan named Karassiak, he is six siblings, but only Rangga converted to Islam, while the others stick to the belief of their ancestor, Aluk Todolo. Rangga's Islamic journey inspired many people from his family and relatives to embrace Islam.

SidThe duppa lives in Madandan as a Koran teacher, apart from being known as the Kaji teacher, as is usually the Koran teacher who comes from Bugis, also acts as both a silat teacher and an attached teacher. After living for a long time, Siduppa married Rangga, a native Madandan woman.

Islam has become a new religion in Madandan, and has noble teachings, and has a good charm, so that many are interested, among others, because of the large number of religious activities in mosques and ceremonial activities held by Muslims that are of public concern, for example in weddings and organizing the body. In weddings, there is usually an entertainment program such as a tambourine to entertain guests who come, this attracts their attention. Organizing the corpse is interesting because it is different from what they have been doing with burials that follow their custom, namely Aluk Todolo.

Another attraction is because of the preaching carried out by Muslims in a friendly way, Muslims never mention directly to adherents Aluk Todoloas infidels, despite the fact that they are indeed infidels. But to maintain good relations and prevent offense, the term kafir was not immediately assigned to them. ${ }^{48}$

Guidance for people who were still converts at that time was still very limited, while the foundation of the faith of these people was still weak, coupled with the very

\footnotetext{
${ }^{46}$ Grandma Kamal (80 years), Descendant of Rangga from marriage with Ambek Laik, Interview, Madandan Kab. Tana Toraja, 15 October 2019

${ }^{47}$ Grandma Ririn (68 years), Descendant of Rangga, Interview, Madandan Kab. Tana Toraja, 15 October 2019.

${ }^{48}$ Sampe Baralangi (49 years), Principal of MAN Makale School, Interview, Tana Toraja, 15 October 2019
} 
limited knowledge of Islam, this is the reason many of them initially embraced Islam, become apostates and return to their original beliefs. ${ }^{49}$

One of the main problems of da'wah in minority areas is interfaith marriage, marriage is often used as an excuse to convert someone, there are many incidents of Christian men marrying Muslim women after that, after that the woman follows the religion of her husband. The limited development of converts is one of the reasons for this incident.

Rangga has been married four times and all of her husbands are Muslim. One husband is a native Toraja person and is not yet Muslim, but after marrying Rangga, Ambek Laik embraced Islam, but according to Kamal's grandmother ${ }^{50}$ because Ambek Laik was not serious in carrying out the teachings of Islam, Rangga was finally divorced, but it is from this marriage that gave birth to many descendants who still embrace Islam today. Rangga is known in the community as a person who holds fast to Islam and has influence in society.

Madandan at that time was the stage where people began to recognize Islam as a religion that began to be of interest to some of the community, especially people who had kinship with Rangga and people who often interacted with him.

Regional similarities with the Luwu Kingdom which previously embraced Islam contributed greatly to the entry of Islam in Tana Toraja, starting from the personal relationship between Datu Luwu and figures and aristocrats from Tana Toraja, to the occurrence of marriages between those who came from these two regions. paving the way for the entry of Islam in Tana Toraja.

Deddy Mulyana argued that similarities in certain matters such as religion, race (ethnicity), language, education level or economic level would encourage people to be attracted to each other and in turn because of these similarities their communication became more effective. ${ }^{51}$

\section{B. Trade Route}

The Tangdilintin study suggests that according to historical studies of Toraja around the XV century AD, many Javanese Hindu traders came to Tana Toraja bringing commercial products such as keramaik, fine woven cloth, dragon-patterned jugs, Javanese script and Arabic script, and others in Toraja language. these commercial products are called baluk (merchandise). Until now, the remains of some of these commercial products are still kept by several noble families of Toraja. ${ }^{52}$

The history of Toraja records that Javanese Hindu traders no longer played a significant role in trading their products since the end of the XV century AD in Tana

\footnotetext{
${ }^{49}$ Sampe Baralangi (49 Years), Principal of MAN Makale School, Interview, Tana Toraja, 15 October 2019

${ }^{50}$ Grandma Kamal (80 years), Descendant of Rangga from marriage with Ambek Laik, Interview, Madandan Kab. Tana Toraja, 15 October 2019

${ }^{51}$ Deddy Mulyana, Ilmu Komunikasi Suatu Pengantar (Cet. XXVII; Bandung: PT. Remaja Rosdakarya, 2017), p. 117-118.

${ }^{52}$ Tangdilintin, Toraja Sebuah Penggalian Sejarah dan Budaya, (Makassar: Balai Pelestarian Sejarah dan Nilai Tradisional, 2009), p. 55
} 
Toraja. Since then, Bugis traders began to control trade in Tana Toraja, along with the spread of Islam in this area. ${ }^{53}$

Bugis traders who went in and out of Tana Toraja were used as opportunities for propagators of Islam who accompanied the caravan of Bugis traders. Towards the middle of the XVI cent ury AD, the religion of Islam began to be embraced by the Toraja people in the South, especially on the border of the Kapuangan Tallu Batupapan and Endekan traditional areas. The concentration of the spread of Islam is concentrated in the South, because the population in the northern region of Tana Toraja is still small.

The spread of Islamic influence in Toraja is different from that of Javanese Hinduism. Javanese Hindu influence left more influence in Tana Toraja. In some ways, Javanese Hinduism has many similarities with the teachings of Aluk Todolo, for example, the implementation of rituals and customs, symbols and ceremonial equipment, such as gongs, dark colored keris banners and sacrifices. Thus the teachings of Aluk Todolo remain sustainable. This factor causes the influence of Islam to be less influential in a number of customary areas of Tana Toraja. Until the twentieth century, the influence of Islam began to appear in the north, especially thanks to the marriage of Muslim Bugis migrants with local residents. ${ }^{54}$

According to Tangdilintin, the spread of Islam in the southern region of Tana Toraja occurred before Arung Palakka arrived on a conquering mission. According to him, it was Bugis traders who first introduced Islam to the local Toraja residents. After that there was the Arung Palakka expedition which aimed for the mission of expanding and conquering the territory. There were already Bugis traders and local people who had embraced Islam before the arrival of Arung Palakka.

Bigalke focuses more on the Toraja coffee trade network established in 1860 and 1885 , via two routes, the first the Luwu line, which runs from the northern belt through the large Toraja market centers and down to Palopo, the port and palace center of the Luwu Kingdom. This network was built through the encouragement of an Arab descendant, Said Ali, who was married to a royal descendant, and at the same time became his main financier. Said Ali collaborated directly with the three Torajan rulers who arranged for the collection and transportation of coffee to the markets under their control. Said Ali's most important allies were Pong Maramba, which controlled key central markets, and Pong Tiku, the ruler in the north, who dominated the largest sources of coffee production.

The second network stretches from the coffee production area in the southern triangle through a number of rival Toraja market centers and then down to Pare-Pare, the port which served as the exit for the developing Kingdom of Sidenreng. ${ }^{55}$ The influence of coffee as a mainstay commodity at that time led to competition between Luwu and Sidenreng to dominate the coffee trade.

The trade route became effective in introducing Islam to society, because through trade, there was direct contact with people from various walks of life. Trade requires direct interaction between the seller and the buyer, in this continuous interaction there will be a process of getting to know each other personally. If a Muslim

\footnotetext{
${ }^{53}$ Tangdilintin, Toraja Sebuah Penggalian Sejarah dan Budaya (Makassar: Balai Pelestarian Sejarah dan Nilai Tradisional, 2009), p. 56

${ }^{54}$ Tangdilintin, Makassar: Balai Pelestarian Sejarah dan Nilai Tradisional, 2009), p. 56 p. 58

${ }^{55}$ Terance W. Bigalke, Sejarah Sosial Tana Toraja, p. 26-27
} 
trader shows a good personality, it will attract people to recognize his religious background. It is through this kind of interaction that local people are attracted to Islam. This is in line with Sattu Alang's statement that:

"One of the routes of entry of Islam to Tana Toraja is through trade, traders from Luwu, Sidrap and Enrekang come to Tana Toraja to trade and interact with local residents, because of their honesty in trading, the local people have a good impression on them. "s6

There are Bugis merchants who come to Tana Toraja who stay for a long time, so there is more intense socialization with the local population, interactions in daily life, both related to trading activities and matters related to daily life, so that in this association there are traders who are interested in the local Toraja people and continue to marriage. This is as stated by Tangdilintin that:

"Until the twentieth century, the influence of Islam began to appear in the northern region, especially thanks to the marriage of Muslim Bugis migrants with local residents. ${ }^{\prime} 57$

The entry of Islam to Tana Toraja cannot be separated from its relationship with the Enrekang region. During the kingdom era, the Enrekang region which was directly adjacent to Tana Toraja was the territory of the Duri kingdom which was then split into three kingdoms known as Tallu Batupapan consisting of the kingdoms of Alla 'Maluak and Buntu Batu. According to Muhammad Natsir Sitonda, that according to Lontarak Bilang, the King of Gowa-Tallo said that in 1687 the acceptance of Islam in Duri. ${ }^{58}$

Islam in Duri, as an area directly adjacent to Tana Toraja in 1687, will more or less affect the Tana Toraja people, especially those who are directly involved in daily life, as well as those who interact through trade relations.

The trade relations between Tana Toraja and Enrekang, especially the Duri area have been going on for a long time, apart from being in a close-knit area, resulting in an exchange of agricultural products to meet their respective needs, traders from Duri bring their wares to markets in the Tana region Toraja, and vice versa, the agricultural products of the Toraja people are sold in markets in the Enrekang area, thus this trade relationship continues to this day.

Teteaji and Amparita are two names of places of origin for the spreaders of Islam in Tana Toraja, especially in Makale. The arrival of the Teteaji and Amparita people to Makale was partly because Sidenreng was already under Dutch rule, while Guru Siduppa did not want to be ruled by infidels (Dutch). ${ }^{59}$ The displeasure of Guru Siduppa and his relatives with the Dutch colonialists caused them to leave their village and migrate to Tana Toraja.

Guru Siduppa, who came from Teteaji, at the end of the XIX century, was an important figure and was the first to spread Islam in Makale. Guru Siduppa came to

\footnotetext{
${ }^{56}$ Sattu Alang, (65 years old), Professor of Islamic Guidance and Counseling UIN Alauddin Makassar, Interview, Makassar, June 17, 2020

${ }^{57}$ Tangdilintin, Toraja .Sebuah Penggalian Sejarah dan Budaya, p. 57

${ }^{58}$ Muhammad Natsir Sitonda, Sejarah Massenrenpulu, (Makassar: Yayasan Pendidikan Mohammad Natsir, 2013), p. 134

${ }^{59}$ Nurdin Baturante, Toraja Tongkonan dan Kerukunan, p. 116
} 
Kampung Baru, Makale with his children Wa 'Baddu and Umarang and his cousins who were also named Siduppa and $\mathrm{Wa}^{\prime}$ Ammada ', along with other groups. ${ }^{60}$ This is in line with what was stated by Sattu Alang that:

“Guru Siduppa who came from Teteaji came to Makale and Tallu Lembangna, spreading Islam to local residents. They settled and with their families in Kampung Baru, Makale. "61

Guru Siduppa, Umarang and Wa 'Baddu remained in Makale and succeeded in Islamizing, among others: Lai' Biu ', Sok' Alik, Lai 'Riko and Lai' Ta'bi. After these people became Islamic, there was a marriage between: Guru Siduppa married Lai 'Biu, So' Alik married lai 'Riko and Wa' Baddu with Lai 'Ta'bi. ${ }^{62}$

Wa 'Baddu's marriage to Lai' Ta'bi gave birth to four sons, among others: Mada 'Ali (Ambo' Isa), Badullah, Muhammad (Ambo 'Lia) and Baco' Lolo. Due to his broad influence in society, Muhammad (Ambo 'Isa) was Head of Makale for a long time. Meanwhile his brother, Baco Lolo, became the Head of Batupapan. ${ }^{63}$

To continue their lives in Tana Toraja, most of them choose jobs as traders. They built shops to sell and some chose to sell in markets. The profession that their predecessors chose seems to have influenced their descendants, as many of them became traders or self-employed. ${ }^{64}$ Their entrepreneurial spirit is still preserved to this day.

The trade relationship between Tana Toraja and surrounding areas such as Enrekang, Luwu, and Bugis is a necessity, where an area needs trade to occur to meet each other's needs and for the circulation of goods and services, to meet their daily needs.

In Bigalke's search, it has been found that the Bugis community in Ma'kale is located west of Tondok Tondok, where there is a market which was quite important before the Dutch settled in Makale as an administrative center. During the expansion of the coffee trade in the late 19th century, a sizable community of Bugis merchants settled on a small plain known as "Paku", west of Tondon, where they were able to herd their horses in a field surrounded by rice fields. Several others lived south of what is now Ma'kale on a hill providing views of the tondon market below. Before the Dutch arrival, ${ }^{65}$ This shows that the Muslim community has long settled and mingled with the local community.

\section{Path of War}

Before after the conquest attempt by Arung Palakka which was deemed a failure. The Arung Palakka expedition was hampered by many obstacles in the area of Gandasil which is located behind the hills (dead end) of Fort Alla, Enrekang. The Alla region was recorded in history when Arung Palakka tried to conquer Tana Toraja in 1683. Alla's Buntu (Hill) fort, which houses Gandang Batu Sillanan, became one of the hard-toconquer Toraja troops, the Arung Palakka joint force which in historical records has

${ }^{60}$ Nurdin Baturante, Toraja Tongkonan dan Kerukunan, p. 116

${ }^{61}$ Sattu Alang (65 years), Professor of Islamic Counseling Guidance at UIN Alauddin, Interview, Makassar, July 5, 2020

${ }^{62}$ Nurdin Baturante, Toraja Tongkonan dan Kerukunan, p. 116

${ }^{63}$ Nurdin Baturante, Toraja Tongkonan dan Kerukunan, p. 116

${ }^{64}$ Nurdin Baturante, Toraja Tongkonan dan Kerukunan, p. 121-122

${ }^{65}$ Terance W. Bigalke, Sejarah Sosial Tana Toraja, p. 96-97 
reached 50,000 In fact, many have fallen victim to the cleverness of the Toraja troops in controlling the terrain by taking advantage of the geographical conditions of the hills to defend and attack. It was stated that apart from carrying out the mission of conquering to expand the territory, Arung Palakka's troops were also said to carry the mission of Islamizing the conquered area. ${ }^{66}$

Aru Palakka's troops entered Tana Toraja around the middle of the XVII century. Tandilinting believes that the arrival of Aru Palakka troops in the 1680s, with the help of Bugis traders who already know the sit uation in Tana Toraja. These troops controlled the southern and central regions, which is known in Toraja history with the Kasaeanna To Bone incident which means the arrival of the Bone people. For too long, Aru Palakka soldiers supported by Bugis traders were able to control most of the Tana Toraja area for several years. Thus, the joints of Bugis culture also influenced the life of the Toraja people. ${ }^{67}$

In the year that Aru Palakka's troops arrived in Tana Toraja, the Kingdom of Bone had long accepted Islam as the official religion of the kingdom, namely since 1611. As stated by Sewang that, after being defeated in the war, Raja Bone Latenripale Toakkepeang, along with his people converted to Islam in 1611.68

The presence of Bone people who have long embraced Islam, it is difficult to say that he did not have any influence on the spread of Islam in Tana Toraja. But there is no strong evidence other than the existence of the Bugis who married the local population. Even so, many people say that the arrival of Aru Palakka's troops was for trading and gambling purposes.

Islam in Rembon, according to Muhammad Kala'tina, was originally spread by four brave men from Bugis, who were originally brought in to help Pong Tiku fight against the Dutch, around 1906. The four people were Ua 'Kambolong, Malloco, Lacanning and Makkawaru. After the war, these four people settled in Toraja and married a woman from Bugis as well. ${ }^{69}$ Thus, the presence of Islam in Rembon was also indirectly caused by war.

\section{CONCLUSION}

The entry of Islam in Tana Toraja began with the interaction of the local community with traders from Bugis Luwu, Bone and Sidenreng, then followed by the Islamization of two Toraja nobles, namely Puang Sondong in Batualu and Rangga in Madandan, both of whom converted to Islam because of marriage, Puang Sondong married Sabarra. 'na and Sabanni'na who came from Suli Luwu, around 1750, Rangga married Opu Daeng Makkalu' who also came from Luwu, around 1865.

\footnotetext{
${ }^{66}$ Paisal, Al-Qalam Journal, Balai Penelitian dan Pengembanbangan Agama, Volume 2 Desember 2019.Institute for Research and Development of Religion, Volume 2 December 2019.

${ }^{67}$ L T Tangdilintin, Toraja Sebuah Penggalian Sejarah dan Budaya, p. 58

${ }^{68}$ Ahmad M. Sewang, Islamisasi Kerajaan Gowa: Abad XVI sampai Abad XVII, (Jakarta: Yayasan Obor Indonesia, 2005), p. 119

${ }^{69}$ Muhammad Kala'tina (68 years), head of the Tana Toraja Islamic Organization and Islamic Religious Leaders in Rembon, Interview, Rembon, Kab. Tana Toraja, 16 October 2019.
} 


\section{DAFTAR PUSTAKA}

Baturante, Nurdin, Toraja Tongkonan dan Kerukunan, Makassar: Pustaka Al-Zikra, 2018

Berger, Charles R. Planning Strategic Interaction: Attaining Goals Thraugh Communicative Action Mahwah, NJ: Lawrwncw Erlbaum, 1997 dalam Stephen W. Littlejohn dan Karen A. Foss, Theories of Human Communication, Jakarta: Salemba Humanika, 2009.

Bigalke, W. Terance, Tana Toraja: A Social History of an Indonesian People, Terj. M. Yuanda Zara, Sejarah Sosial Tana Toraja, Yogyakarta: Ombak, 2019.

Bogdan, Robert dan Steven J. Tailor. Dasar-Dasar Penelitian Kualitatif. Terj. A. Khosin Afandi. Surabaya: Usaha Nasional, 1993.

Cangara, Hafied. Perencanaan dan Strategi Komunikasi. Jakarta: Raja Grafindo Persada, 2013.

Hadaru, Nawawi. Metode Penelitian Bidang Sosial. Yogyakarta: Gajah Mada University Press, 1993

Litlejohn, Stephen W. dan Karen A. Foss. Teori Komunikasi, Jakarta: Salemba Humanika, 2009.

Mattata, Sanusi Dg, Luwu dalam Revolusi, Cet. II; Makassar: Bhakti Baru, 1962.

Mulyana, Deddy. Metodologi Penelitian Kualitatif: Paradigma Baru Ilmu Komunikasi dan Ilmu Sosial Lainnya, Bandung: PT. Remaja Rosdakarya, 2002.

. Ilmu Komunikasi Suatu Pengantar, Cet XX1; Bandung: PT. Remaja Rosdakarya, 2017.

Nawawi, Hadaru. Metode Penelitian Bidang Sosial, Yogyakarta : Gajah Mada University Press, 1990.

Pawito, Penelitian Komunikasi Kualitatif, Yogyakarta: LKIS, 2008.

Samavar, Larry A. Ricard E. Porter, dan Edwin R. McDaniel, Communication Between Cultures, Terj. Indri Margaretha Sidabalok, Komunikasi Lintas Budaya, Edisi VII; Jakarta: Salemba Humanika, 2010.

Sugiyono, Metode Penelitian Kombinasi (Mixed Methods), Bandung: Alfabeta, 2013.

Sulasman, Metodologi Penelitian Sejarah: Teori Metode Contoh Aplikasi, Bandung: Pustaka Setia, 2014

Taufik, Tata, Etika Komunikasi Islam, Cet. I; Bandung: Pustaka Setia, 2012.

West, Richard dan Lynn H. Turner, Pengantar Teori Komunikasi; Analisis dan Aplikasi Edisi 3 Buku 2 (Penj. Maria Natalia Damayanti Maer). Jakarta: Salemba Humanika. 2008. 